\title{
Flash floods and debris flow in the city area of Messina, north-east part of Sicily, Italy in October 2009: the case of the Giampilieri catchment
}

\author{
G. T. Aronica ${ }^{1}$, G. Brigandí ${ }^{1}$, and N. Morey ${ }^{2}$ \\ ${ }^{1}$ Department of Civil Engineering, University of Messina, Messina, Italy \\ ${ }^{2}$ Department of Physics, University of Messina, Messina, Italy \\ Correspondence to: G. Brigandí (gbrigandi@unime.it)
}

Received: 22 April 2011 - Revised: 23 October 2011 - Accepted: 3 January 2012 - Published: 7 May 2012

\begin{abstract}
This paper concerns the analysis of the 1 October 2009 flash flood and debris flow event caused by a very intense rainfall concentrated over the Messina area. The storm caused severe flash floods in many villages around the city of Messina, such as Giampilieri, Scaletta Zanclea, Altolia Superiore and Molino, with 38 casualties and significant damages to property, buildings, roads and bridges estimated close to 550 million Euro. The main focus of this work is to perform a post event analysis, putting together available meteorological and hydrological data in order to get better insight into temporal and spatial variability of the rain storm, the soil moisture conditions and the consequent flash flood in the Giampilieri catchment. The event was investigated using observed data from a raingauge network. Statistical analysis using GEV distribution was performed and rainfall return period (storm severity) was estimated. Further, measured rainfall data and rainfall-runoff modelling were used to estimate soil moisture conditions, to analyse the hydrological behaviour and to reconstruct flood hydrograph. With the help of GIS technology and particularly spatial analysis, the volume of debris which has gone down into the Giampilieri village was also calculated. GIS maps with landslide and material deposit areas were produced and analysed.
\end{abstract}

\section{Introduction}

A flash flood is defined as a flood which follows shortly (i.e. within a few hours) after a heavy or excessive rainfall event (Georgakakos, 1986; Sweeney, 1992; Borga et al., 2007) and consequently, the important hydrologic processes are occurring on the same spatial and temporal scale as the intense precipitation. These kinds of events represent an important problem in Europe, especially in many Mediterranean catchments, as well as in many other temperate areas in the world, resulting from severe rain clouds, which can produce thunderstorms or (Doswell III et al., 1996) mainly of convective origin that occur locally, typical in these regions.

Flash floods can cause serious damages and economic losses. For example, an estimated $€ 1.2$ billion Euro damages were caused in the Gard (France) 2002 single flash flood event (Huet et al., 2003), € 65 million Euro in the 2000 Magarola (Spain) flash flood (Llasat et al., 2001), € 300 million Euro in the 1994 Pinios (Greece) flash flood (Gaume et al., 2008 ) and $€ 4.6$ million Euro in the 2007 Mastroguglielmo (Italy) flash flood event (Aronica et al., 2008). Importantly, flash floods and debris flow also pose a serious risk to people, as water depths and velocities can increase within a short time. Past flash floods and debris flow have often caused high numbers of casualties; over 80 people, for example, lost their lives in the 1996 Biescas flood in Spain (Alcoverro et al., 1999), 47 people died in the flash flood on the Malá Svinka River in Slovakia in 1998, 23 people lost their lives in the Gard 2002 flood, 2 people died in the flash flood and debris flow on Cable Canyon in San Bernardino County in California in 2003 (USGS, 2005) and 19000 people lost their lives in the Cordillera de la Costa, Vargas (Venezuela) flash flood and debris flow disaster in 1999 (USGS, 2001).

As occurs in practically all Mediterranean countries, most of the catchments in the north-east part of Sicily (Italy) are small, with a steep slope, and characterised by short concentration times. Moreover, most of the slopes are poorly vegetated and, consequently, rainfall that is normally absorbed by vegetation can run off almost instantly. All these characteristics make those catchments prone to flash flood formation, as demonstrated by events that occurred in the area around Messina in recent years. The events which took place on 25 October 2007 in the Mastroguglielmo torrent on the

Published by Copernicus Publications on behalf of the European Geosciences Union. 
Ionian Sea coast, on 11 December 2008 in the Elicona catchment on the Tyrrhenian sea coast and on 1 October 2009 in Racinazzi and Giampilieri torrents on the Ionian Sea coast are examples of flash floods and debris flow that caused not only significant economic damages to property, buildings, roads and bridges but also, in the case of the 1 October 2009 event, loss of human life.

During this last event, in fact, a devastating flooding was caused by a very intense rainfall concentrated over Sicily particularly affecting the area of Messina and being responsible for the destruction of numerous structures and goods and for 38 casualties. Many villages were involved such as Giampilieri, Scaletta Zanclea, Altolia Superiore and the damages were estimated close to 550 million Euro (Regional Department of Civil Protection for Sicily, 2009).

The main focus of this work is to describe and analyse the flash flood and debris flow event which affected the area of Giampilieri (Sicily) on 1 October 2009 by putting together available meteorological and hydrological data in order to get better insight into temporal and spatial variability of the rain storm, the soil moisture conditions and the consequent flash flood in the catchment of the Giampilieri torrent. Further, the debris flow volume was calculated using GIS tools. The choice of this case study to perform a post-event analysis was aimed not only by the severity of the event, but especially because this was the first case in Sicily in which so many post-event data were available. In order to perform a post-event analysis like the one carried out in this paper, it is necessary have information, especially for the debris flow volume computation, that was not available for other past events that occurred in the same region or in another similar areas.

\section{Main characteristic of study area}

The small village of Giampilieri is located on the Ionian Sea coast in the north-eastern part of Sicily, $20 \mathrm{~km}$ south-east from the city of Messina.

The area of the catchment is approximately $10 \mathrm{~km}^{2}$ with an elevations range between 0 and $1056 \mathrm{~m}$ a.s.l. and an average value of $513 \mathrm{~m}$ a.s.l. (Fig. 1). The topography is very rugged and the slope is steep (average value is $28.5^{\circ}$ and a maximum value is $73.9^{\circ}$ ) as is that of a number of its tributaries, some of which are incised into narrow pathways as they approach the main channel whose length is about $8.5 \mathrm{~km}$. The river network of the catchment is quite divided, especially in the mountainous area where a number of secondary river branches are present. These follow a short, twisted and quite steep main course that flows straight into the valley where the urbanisation affected not only the floodplain but also the river bed itself, posing a serious risk to the village of Giampilieri Marina whose main roads were previously part of the torrent.

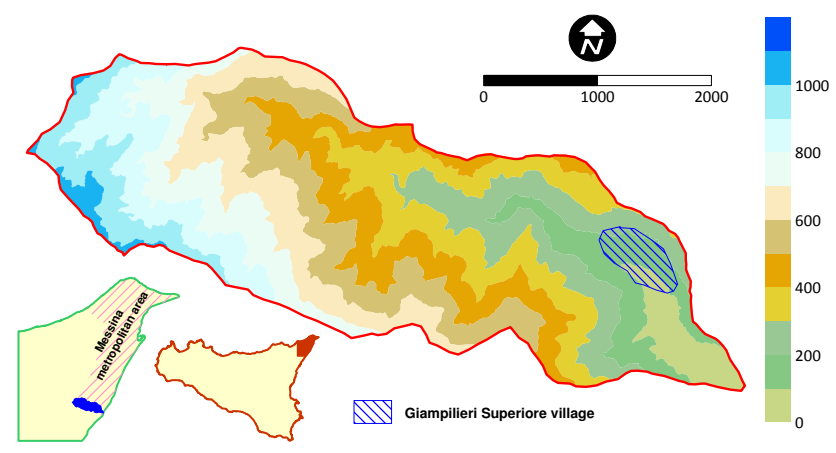

Fig. 1. Location map and topography of the Giampilieri catchment.

Moreover, several slopes have suffered local and global instability processes in the past and the stability conditions of the shallowest portions of most rock slopes are in some cases unsatisfactory due to the poor geotechnical properties of the cover soils. The catchment is predominantly rural with grassland and crop cultivation ( $46 \%$ ) and shrubs and sparse forest $(42.4 \%)$ in the upper mountainous part, while some areas $(7.3 \%)$ in the valley floor are highly urbanised (Giampilieri village).

The climate is typical Mediterranean, with rainfall events (mainly convective) characterised by short durations and high intensities during the wet season (October-April) and few events during the dry season (May-September). The mean annual rainfall is about $970 \mathrm{~mm}$ with about $84 \%$ in the wet season and about $16 \%$ in the dry season. Moreover, the substantial load of solid material that these rivers carry following heavy rainfall constitutes a serious problem, particularly when overflow occurs in the more densely populated territories.

The geology of the area is characterised by a bedrock, outcropping on more than $80 \%$ of the area, mainly formed by meta-sedimentary terrain belonging to the Peloritani Belt (PB) that represents the westernmost part of the CalabriaPeloritani Arc (CPA). Only subordinately alluvial deposits and pleistocenic conglomerates are present. Phyllites and metarenites develop a soil cover especially at medium/low elevations ASL as the result of weathering; the thickness of colluvium is in the range 1.0-3.0 $\mathrm{m}$ (Messina et al., 1996).

\section{Event description}

On the afternoon of 1 October 2009, a deep cyclone developed in the southern part of the Mediterranean basin producing an intense rainstorm over Sicily, particularly affecting the area of Messina (Fig. 2). During the course of the event, the persisting rainfall in the Ionian Sea coast around Messina caused a number of landslides, flash floods and debris flow that blocked the road system as well as the railway and the motorway, making the already critical state caused by the adverse weather conditions of the last half of September worse. 


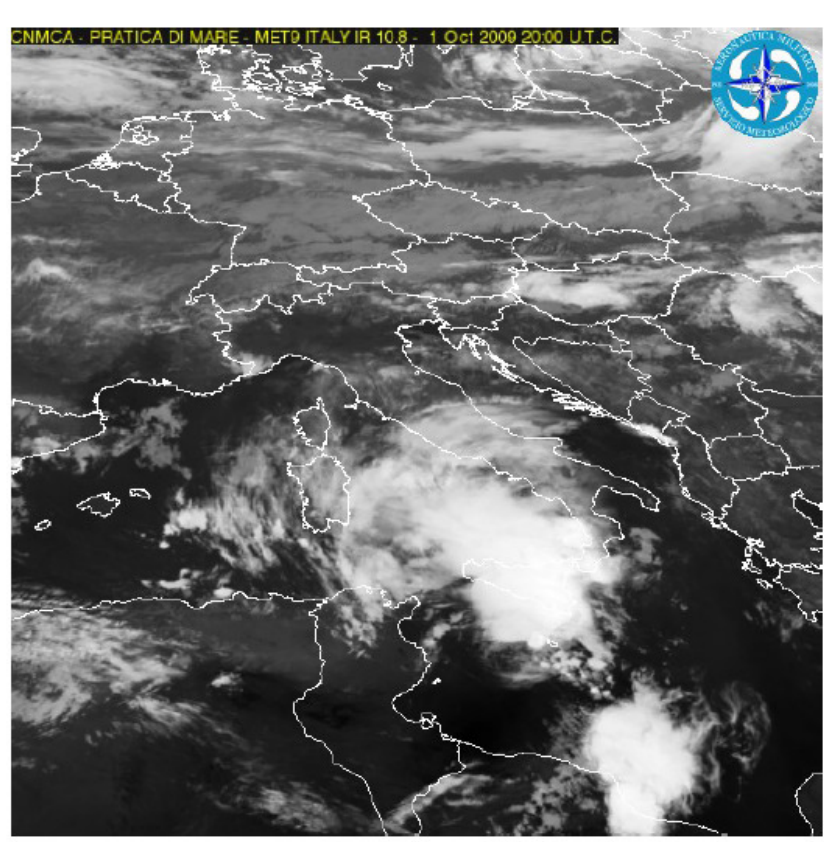

Fig. 2. Satellite image of the huge convective system affecting the eastern part of the Sicily (source: Regional Department of Civil Protection for Sicily).

The area around Messina, and specifically the analysed area of this study, was, in fact, subjected to unstable weather with high values of precipitation during all of September; total monthly rainfall of September 2009 recorded at various raingauge stations around Giampilieri catchment (Fig. 3) was characterised by much higher-than-average values derived on the basis of the available data for September period for the years from 1920 up to 2005 (Fig. 4). In particular, since the last half of September 2009, the analysed area was affected by a series of rainstorms characterised by heavy and intense rainfalls. The events that took place on the 16th, the 23rd and the 24th of the same month caused the catchment saturation at the beginning of October, as the post event analysis reported below shows.

The flash flood and debris flow triggered by heavy rainfall on the 1 October 2009 locally involved property, buildings, roads and bridges (Fig. 5) and blocked traffic for many hours; 38 people lost their lives and damages close to 550 MEuro were estimated (Regional Department of Civil Protection for Sicily, 2009).

During the late evening, the village of Giampilieri suffered a number of landslides that hit its population and caused the collapse of some buildings. The A/18 Messina-Catania Motorway, the State Road 114 and the Giampilieri-Scaletta rail line were closed due to the landslides.

For the analysis of the event, Messina Ganzirri, Messina Istituto Geofisico, Colle San Rizzo, S. Stefano Briga, Fiumedinisi and Antillo raingauge stations, whose locations are shown in Fig. 3, were used. Only those raingauges, in fact, worked at the time of the event.

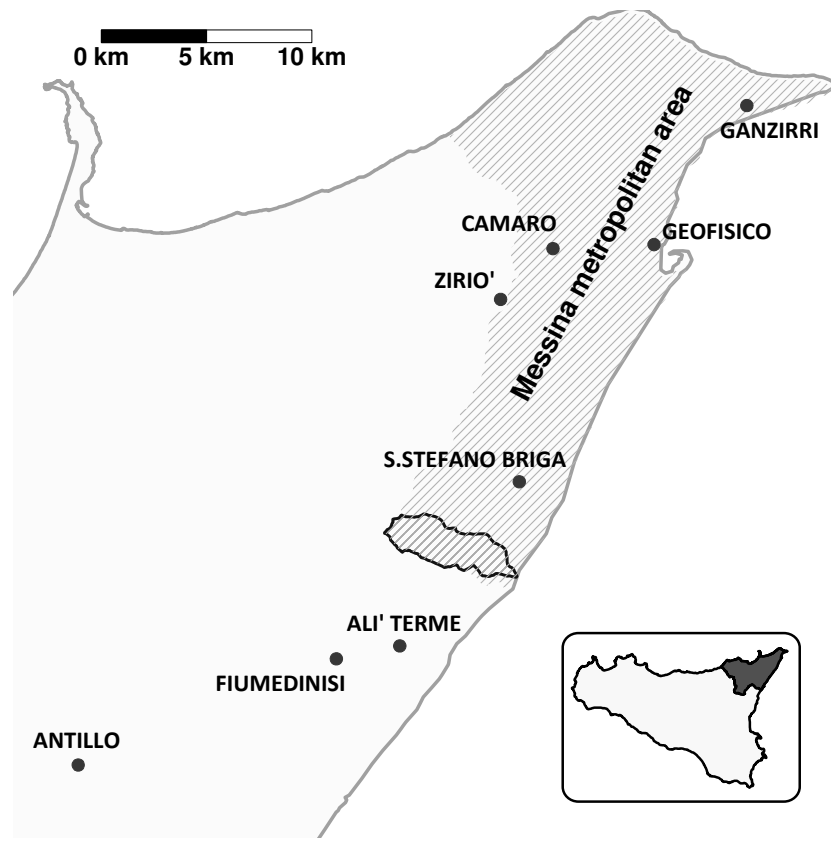

Fig. 3. Location of raingauge stations used for the study.

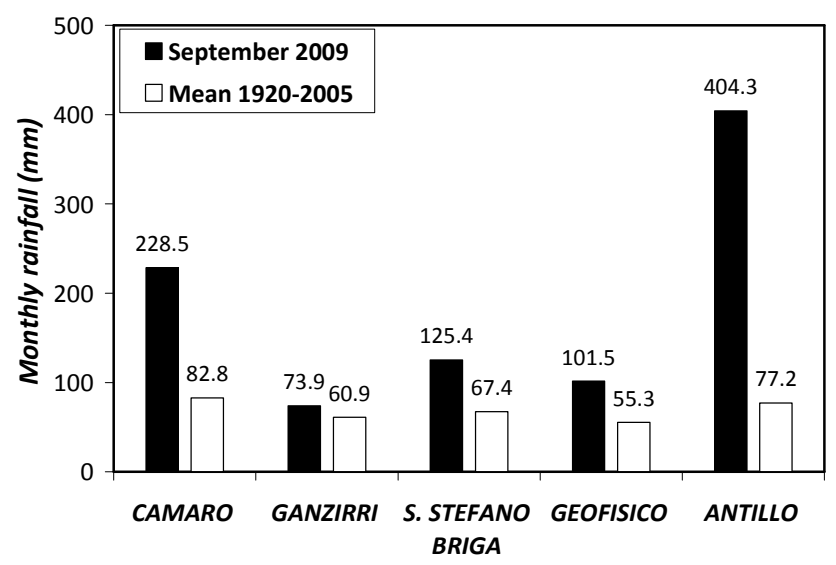

Fig. 4. September Monthly rainfall.

Rainfall maps (Fig. 6), derived by interpolating available data through kriging, show how the storm covered the southern part of the city of Messina and was concentrated on the Ionian Sea coast and mainly in the area around Giampilieri. As Fig. 6 shows, the event happened over a few hours; more than $220 \mathrm{~mm}$ of rain fell in less than 4 hours with a peak of about $120 \mathrm{~mm} \mathrm{~h}^{-1}$ in 10 -min.

The cumulated events represented in Fig. 7 show how the event was mainly concentrated in Santo Stefano Briga and Fiumedinisi raingauge stations, where data collected are characterised by much higher values than the others, concerning both the total cumulative rainfall (Fig. 7) and the 10min rainfall intensity (Fig. 8). 

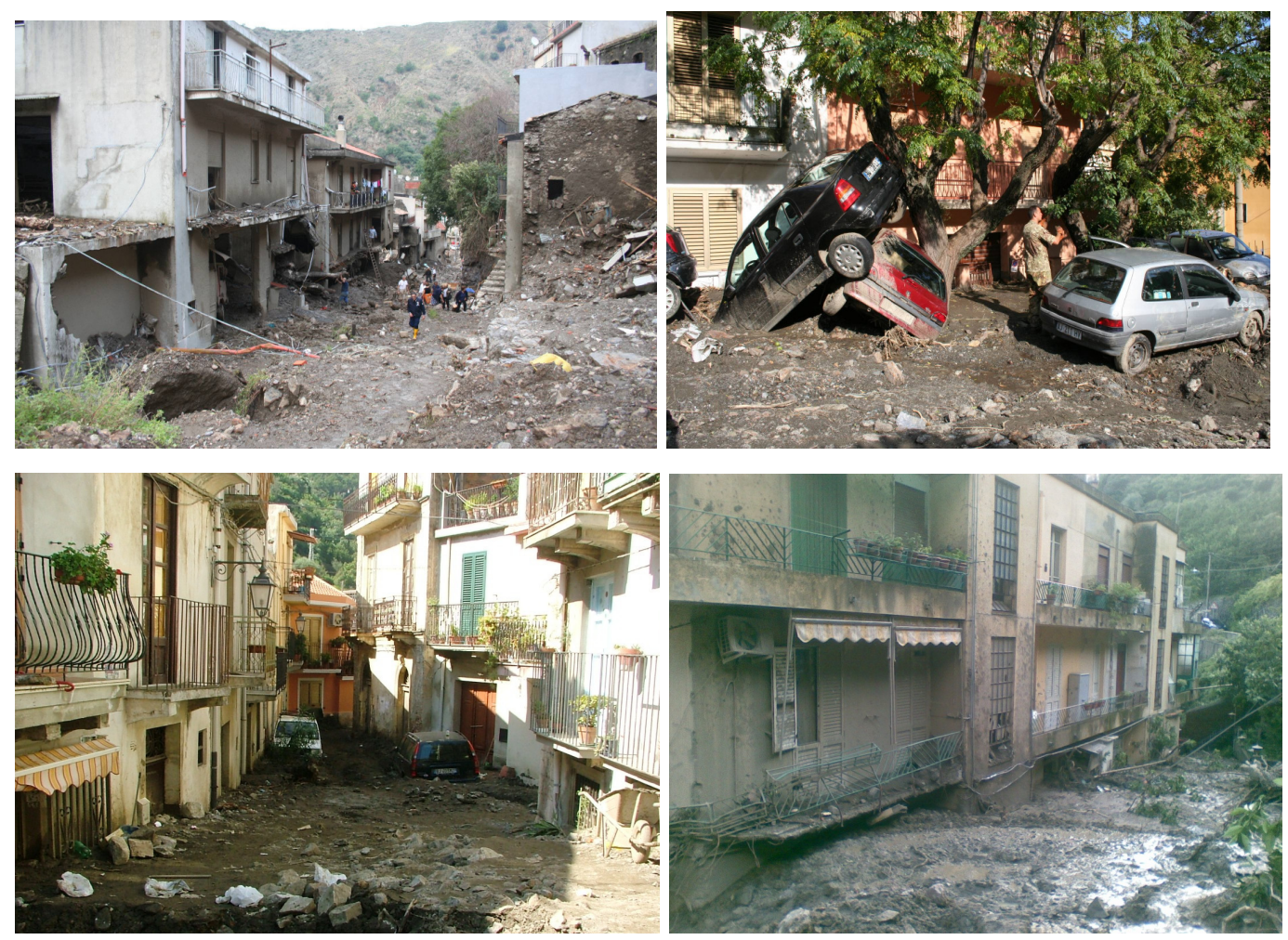

Fig. 5. Snapshots from flooded area in Giampilieri village.
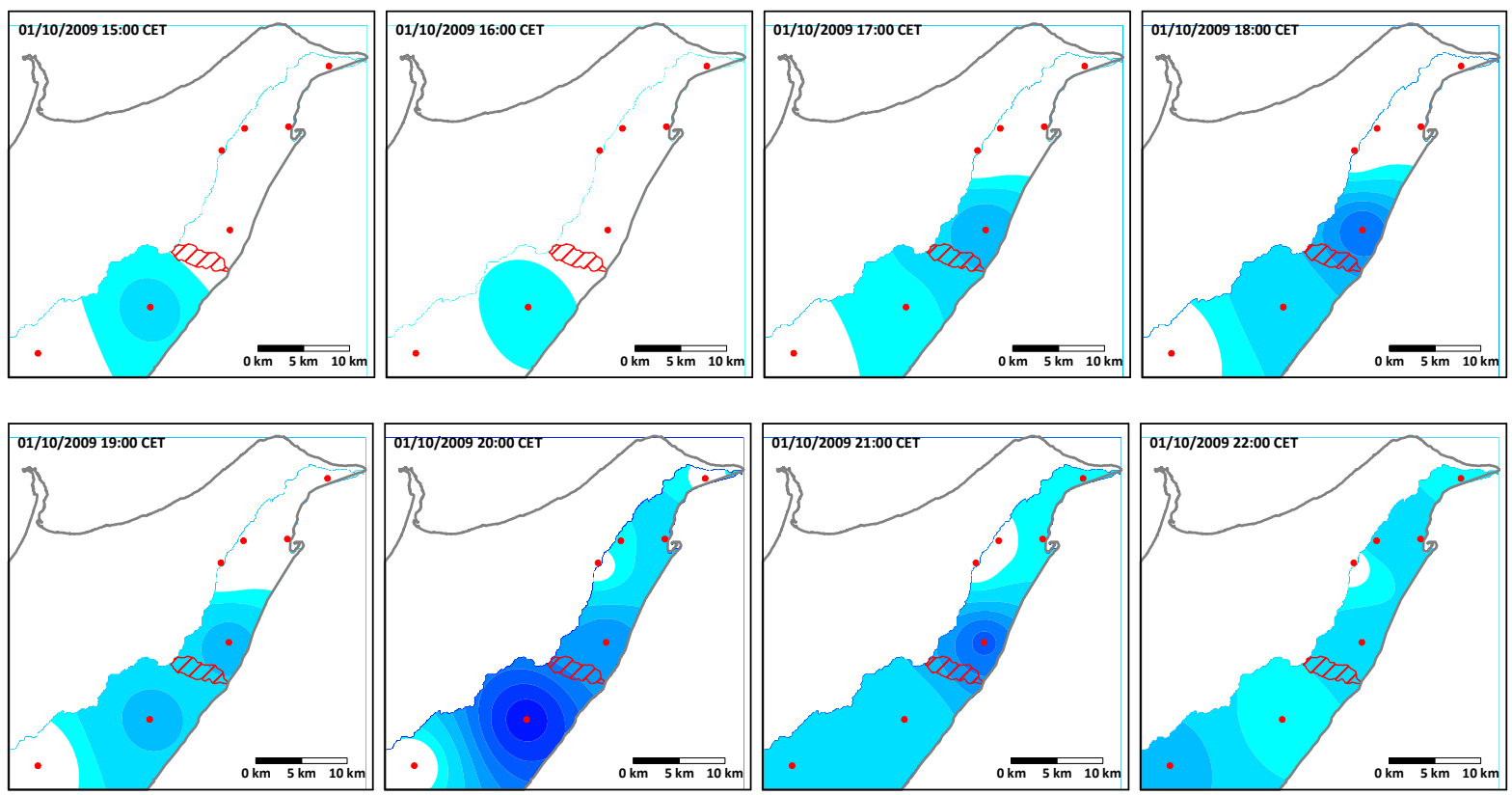

Rainfall depth (mm)

$\begin{array}{lllllllll}5 & 10 & 20 & 30 & 40 & 50 & 60 & 70 & 80\end{array}$

Fig. 6. Total rainfall $(\mathrm{mm})$ time evolution maps. 


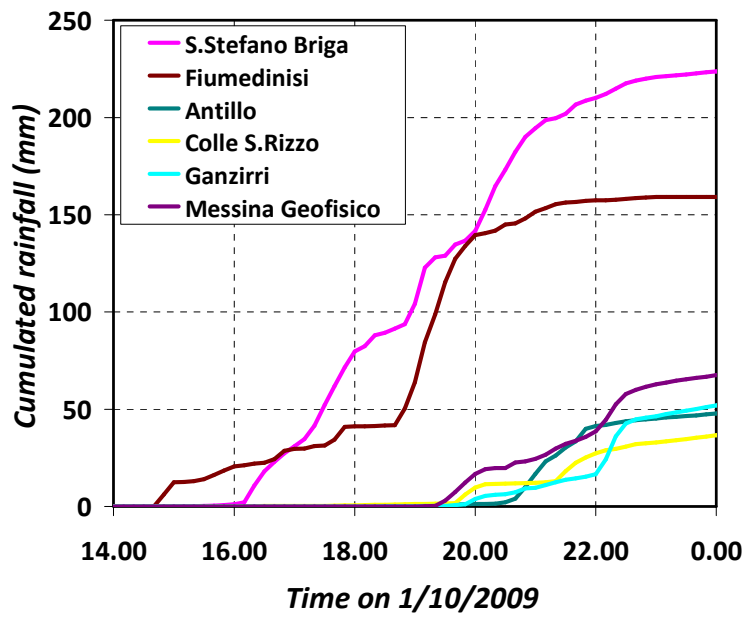

Fig. 7. Cumulative hyetographs recorded at the raingauge stations.

\section{Hydrological analysis}

\subsection{Storm severity}

In order to evaluate the return period of the event, the depthduration-frequency (DDF) curves for different return periods were derived in the following form:

$h_{\mathrm{d}, T}=K_{T} \times \mu_{\mathrm{d}}(d)$

where $\mu_{\mathrm{d}}(d)$ represents the relationship between mean and duration and $K_{T}$ is the probability distribution of the frequency factor, called growth curve, which represents the $T$-years quantile of the normalised statistical distribution.

For this analysis three statistical distributions were considered:

- Two components extreme value (TCEV) distribution (Rossi et al., 1984), developed, in the VAPI project, by the Italian National Research Group for the Prevention of Hydro-Geological disaster, and usually adopted in Italy for extreme rainfall frequency analysis at regional scale;

- the generalized extreme value (GEV) distribution, introduced by Jenkinson (1955), usually adopted because of its capability to reproduce the extreme precipitation characteristics and applied for the analysis of extreme rainfall and floods in different Italian regions (Norbiato et al., 2008; Noto and La Loggia, 2009);

- the Gumbel distribution in scale invariance formulation. The complete mathematical description is beyond the scope of this report, but can easily be found in literature (i.e. Burlando and Rosso, 1995).

By using TCEV distribution, the analysis was performed through the use of the statistical methods involving regionalisation based on annual maximum data (Cannarozzo et al.,

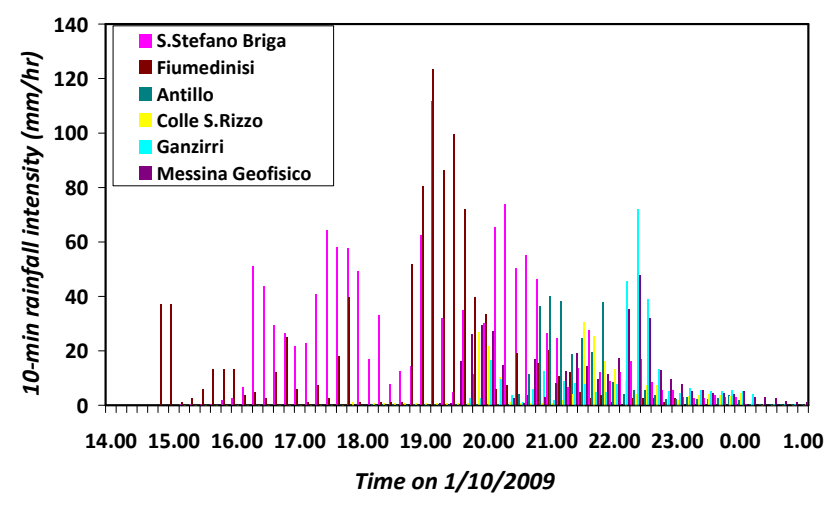

Fig. 8. 10-min rainfall intensity recorded at the raingauge stations.

1995). The procedure followed assumes that within a region ("homogeneous region"), the frequency distribution of the rainfall is the same at all sites except for a scaling factor represented by the mean of the site-specific data that may vary from site to site. The cumulative distribution function (CDF) of the TCEV distribution, representing the growth curve, has the following form:

$$
T=\frac{1}{1-\exp \left[-\Lambda_{1}(\exp (\alpha))^{-K_{T}}-\Lambda^{*}\left(\Lambda_{1}\right)^{\frac{1}{\Theta^{*}}}\left(\exp \left(\frac{\alpha}{\Theta^{*}}\right)\right)^{-K_{T}}\right]}
$$

where $\alpha, \Lambda_{1}, \Lambda^{*}, \Theta^{*}$ are the four parameters and $K_{T}$ is the normalised quantile. Cannarozzo et al. (1995) estimated the four parameters $\alpha, \Lambda_{1}, \Lambda^{*}, \Theta^{*}$ at different levels of regionalisation for Sicily. In their work the authors calculated the TCEV parameters $\Lambda^{*}$ and $\Theta^{*}$, considering the entire island a single homogeneous region by using the $1,3,6,12$ and $24 \mathrm{~h}$ duration annual maximum rainfall. With regard to this first level of regionalisation, those two parameters, for the reference duration equal to $1 \mathrm{~h}$, were estimated by Cannarozzo et al. (1995) as equal to 0.175 and 1.978 , respectively. At second level of regionalisation, Sicily was divided into three hydrologically homogeneous sub-regions in which the $\Lambda_{1}$ and $\alpha$ parameters were assumed constant. With regard to this second level of regionalisation, the two TCEV parameters for the sub region where our study area is located within (subregion B) were respectively estimated equal, for the reference duration equal to $1 \mathrm{~h}$, to 12.4 and 3.354 .

Aggregated rainfall data, and in particular the 1, 3, 6, 12 and $24 \mathrm{~h}$ duration annual maximum rainfall, coming from Alí Terme and Camaro raingauge stations (Fig. 3) were, instead, used to evaluate the depth-duration-frequency (DDF) curves by applying GEV and EV1 probability distributions. Only those raingauges were considered because the size of the historical sample available at the other stations did not allow any statistical inference because of the few available years of data collected. The period of data collection at selected sites was from 1929 to 2000 for the Camaro station and from 1959 to 2000 for the Alí Terme Station. 


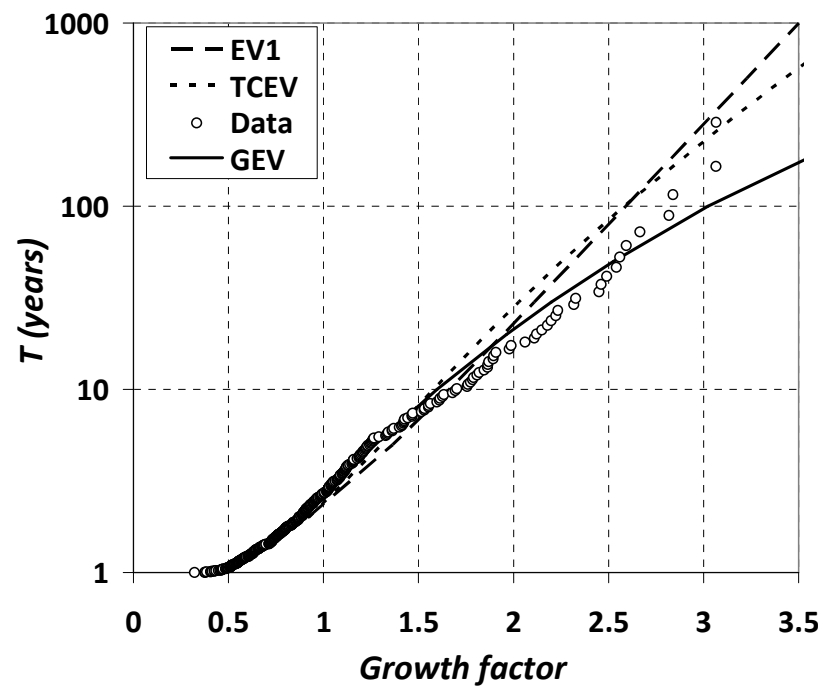

Fig. 9. Growth curves for the statistical distributions considered.

Parameter estimation for the GEV and EV1 distributions was carried out using the method of $L$-moments (Hosking and Wallis, 1997) because they are less prone to adverse sampling effects than conventional moments yielding more robust and more accurate quantile estimates (Kottegoda and Rosso, 1998; Hosking and Wallis, 1988). For this, which concerns the generalized extreme value (GEV) distribution with parameters $u$ (location), $\alpha$ (scale) and $\kappa$ (shape), the growth curve is given by the following:

$K_{T}=u+\frac{\alpha}{\kappa}\left\{1-\left[\ln \left(\frac{T}{T-1}\right)\right]^{\kappa}\right\}$

The parameters of the GEV distribution in terms of $L$ moments are expressed by the following equations (Hosking and Wallis, 1993):

$\alpha=\frac{k L_{2}}{\left(1-2^{-k}\right) \Gamma(1+k)}$

$u=L_{1}-\frac{\alpha}{k}[1-\Gamma(1+k)]$

$$
\begin{aligned}
k= & 7.859 \times\left(\frac{2 L_{2}}{L_{3}+3 L_{2}}-\frac{\ln 2}{\ln 3}\right) \\
& -2.9554 \times\left(\frac{2 L_{2}}{L_{3}+3 L_{2}}-\frac{\ln 2}{\ln 3}\right)^{2}
\end{aligned}
$$

where $L_{1}, L_{2}$ and $L_{3}$ are the first-, second-, and third-order $L$-moments estimated at regional scale using a normalised duration-independent sample obtained by merging the five different normalised samples. The GEV parameters values were respectively estimated equal to -0.2096 for the shape parameter $\kappa, 0.755$ for the location parameter $u$, and 0.2930 for the scale parameter $\alpha$.

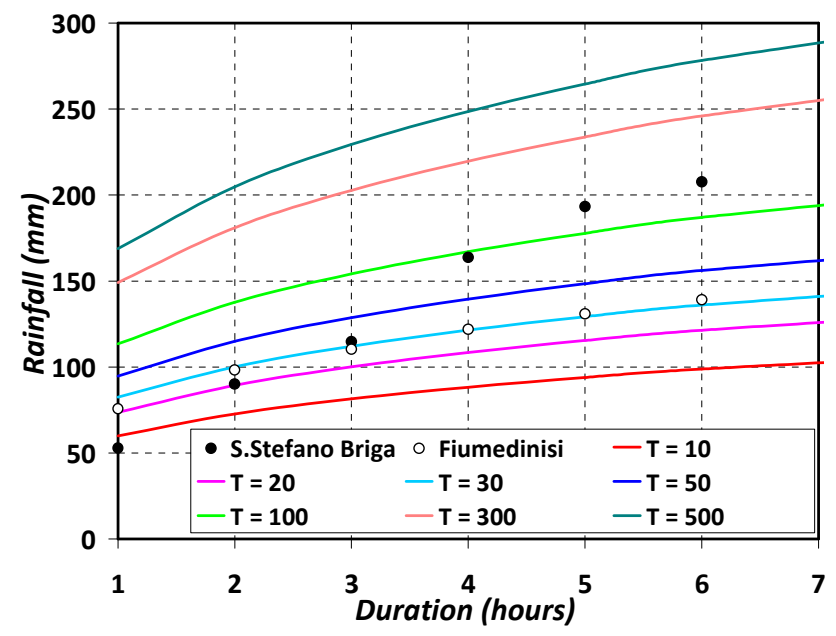

Fig. 10. Return period of the rainfall event.

Finally, the growth curve for the Gumbel distribution has the following form:

$K_{T}=1-\mathrm{CV}\left\{0.45+0.779 \times \ln \left[\ln \left(\frac{T}{T-1}\right)\right]\right\}$

The parameters of the EV1 distribution in terms of $L$ moments are expressed by the following equation:

$\mathrm{CV}=\frac{1.283}{\ln 2} \times \frac{L_{1}}{L_{2}}$

where $L_{1}$, and $L_{2}$ are the first and the second order $L$ moments estimated, as above, at regional scale using a normalised duration-independent sample obtained by merging the five different normalised samples. The EV1 parameter $\mathrm{CV}$ value was estimated equal to 0.5074 .

Growth curves for the TCEV, GEV and EV1 distributions along with the empirical normalised quantile based on Hazen plotting position (Kottegoda and Rosso, 1998) are shown in Fig. 9. As the figure shows, the GEV distribution looks to be the most appropriate distribution to characterise the analysed data. This hypothesis was well supported by the application of the goodness of fit Kolmogorov-Smirnov test to the sample, with a significance level equal to 0.05 . The results are shown in Table 1 and they confirm that the GEV distribution is the most appropriate probability function to characterise the available sample. Consequently, it was adopted for the derivation of the DDF in order to characterise the return time both of the event and of the sub-event of maximum duration (Fig. 10, Table 2).

The results show a large difference in the rainfall return period estimation both for all duration and for each raingauge station. The maximum hourly rainfall for the analysed storm was equal to about $208 \mathrm{~mm}$ for Santo Stefano Briga station; hence, its annual probability was estimated as the equivalent of a 1 in $150 \mathrm{yr}$ return period. However, the maximum hourly rainfall for the analysed storm was equal to about $150 \mathrm{~mm}$ for 
Table 1. Goodness of fit Kolmogorv-Smirnov test.

\begin{tabular}{lrrl}
\hline $\begin{array}{l}\text { Probability } \\
\text { Distribution }\end{array}$ & $\begin{array}{r}d= \\
\max |F(x)-P(x)|\end{array}$ & $D_{N, \alpha}$ & $\begin{array}{l}\text { Test: } \\
d<D_{N, \alpha}\end{array}$ \\
\hline GEV & 0.024 & 0.069 & VERIFIED \\
EV1 & 0.079 & 0.069 & NOT VERIFIED \\
TCEV & 0.103 & 0.069 & NOT VERIFIED \\
\hline
\end{tabular}

the Fiumedinisi station; hence, its annual probability was estimated as the equivalent of a 1 in $30 \mathrm{yr}$ return period (Fig. 10, Table 2). This large difference gives the idea of a rainfall event extremely concentrated in space. Particularly interesting is that this concerns the sub-event of maximum duration equal to three hours, a time after which major damages were observed; in this case the annual probability estimated for Santo Stefano Briga station was equivalent of a 1 in $33 \mathrm{yr}$ return period and for Fiumedinisi station was equivalent of a 1 in $28 \mathrm{yr}$ return period. Both of these values suggest that, also if the return time of the rainstorm allows to assert that it was an extreme event, the sub-event that was responsible for all consequences was characterised by a return time much less, which suggests its classification as not severe. This implies that post-flood investigation should focus on other characteristics, such as discharges and soil moisture conditions, rather than simply analysing statistical characteristics of rainfall.

\subsection{Flood hydrograph}

For the reconstruction of the flood hydrograph, because we are dealing with an ungauged catchment, the choice was orientated towards the use of a simple lumped rainfall-runoff model based on the Instantaneous Unit Hydrograph IUH for flood routing and Soil Conservation Service-Curve Number (SCS-CN) method for runoff generation (Chow et al., 1988).

First of all, the spatially averaged pluviometric information was obtained using the rainfall maps shown in Fig. 6; then the rainfall-runoff transformation, for $\mathrm{AMC}_{\mathrm{III}}$ antecedent soil moisture condition (wet soil) for which $\mathrm{CN}_{\mathrm{III}}$ was estimated equal to 88 , was carried out through the application of SCS-CN procedure (USDA NEH-4 procedure, 1986; Mishra and Singh, 2003), implemented on the basis of the "time dependent" formulation. The SCS-CN method is, in fact, in the original conception, a cumulative model; this implies that is not possible to take account of the temporal evolution of the rainfall. Hence, in order to overcome this limitation, for the rainfall-runoff transformation, the SCS dynamic approach was used (Chow et al., 1988).

Various methods are provided for determination of $\mathrm{UH}$, from which kinematic IUH (Maidment, 1992), here applied, can be suitable for ungauged catchment. Kinematic IUH requires, in fact, estimation of only two parameters: time of concentration $\left(t_{\mathrm{c}}\right)$ and time-area curve of the catchment,

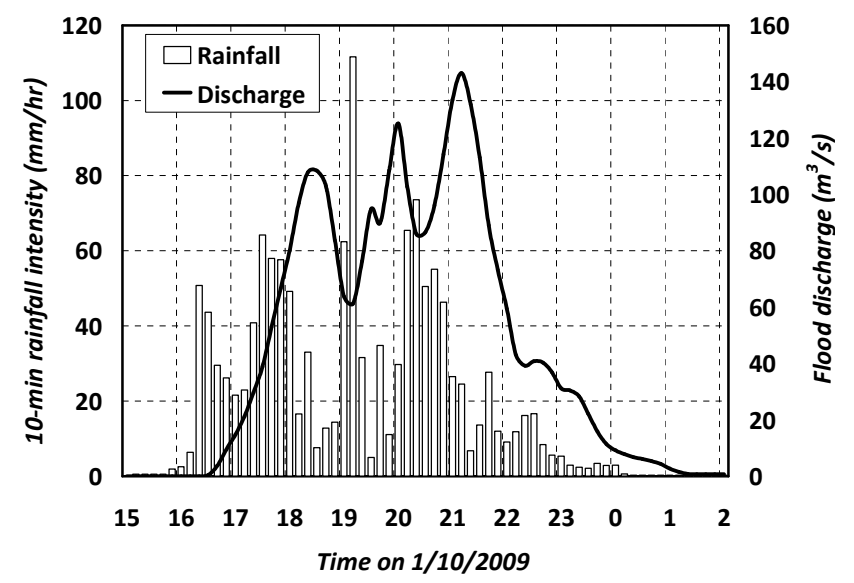

Fig. 11. Reconstructed flood hydrograph.

easily deriving for every kind of catchments by applying GIS techniques. The UH was derived following the approach proposed by Maidment (1992) and using a $2 \mathrm{~m}$ resolution digital elevation model (DEM) of the catchment. The concentration time was estimated using the well known Kirpich formula (Kirpich, 1940) and calculated equal to $70 \mathrm{~min}$. The flood hydrograph so derived is shown in Fig. 11.

For the estimation of the peak discharge return time, a flood frequency analysis based on a Monte Carlo approach (Aronica and Candela, 2007) was performed. The model applied is based on a semi-distributed stochastic rainfall-runoff model composed by three modules: a stochastic rainfall generator module, a hydrologic loss module and a flood routing module. In the rainfall generator module, the rainfall was assumed to follow the two components extreme value (TCEV) distribution whose parameters were estimated at regional scale for Sicily. The catchment response was modelled by using the SCS-CN method, in a semi-distributed form, for the transformation of total rainfall to effective rainfall and simple form of IUH for the flood routing.

Figure 12 illustrates the flood frequency curve obtained for the Giampilieri catchment at the outlet. The analysis of the figure suggests that the annual probability was at the equivalent of a 1 in $130 \mathrm{yr}$ return period. This value confirms a large nonlinearity between return time of the rainfall and return time of the discharge. A rainfall characterised by an annual probability equivalent of a 1 in about $30 \mathrm{yr}$ return period can produce, if combined with other effects, a flooding characterised by an occurrence much more severe.

\subsection{Soil moisture condition}

It is well known in the hydrology literature that soil moisture plays an important factor in flood formation, because the runoff generation is strongly influenced by the antecedent soil moisture conditions of the catchment (Aronica and Candela, 2007). A number of studies (Sturdevant-Rees et al., 
Table 2. Return period of rainfall event.

\begin{tabular}{rrrrrr}
\hline \multirow{2}{*}{ Duration (min) } & \multicolumn{2}{c}{ Rainfall $(\mathrm{mm})$} & & \multicolumn{2}{c}{ Return time (probability) } \\
\cline { 2 - 3 } & Santo Stefano & Fiumedinisi & & Santo Stefano & Fiumedinisi \\
\hline 10 & 18.6 & 20.6 & & - & - \\
20 & 29.0 & 34.0 & & - & - \\
30 & 34.3 & 48.4 & & $7(0.86)$ & $22(0.95)$ \\
60 & 52.9 & 75.8 & & $21(0.95)$ & $28(0.96)$ \\
120 & 90.2 & 98.4 & & $33(0.97)$ & $28(0.96)$ \\
180 & 114.8 & 110.4 & & $93(0.99)$ & $30(0.97)$ \\
240 & 163.8 & 122.0 & & $151(0.99)$ & $33(0.97)$ \\
360 & 207.7 & 139.2 & & &
\end{tabular}

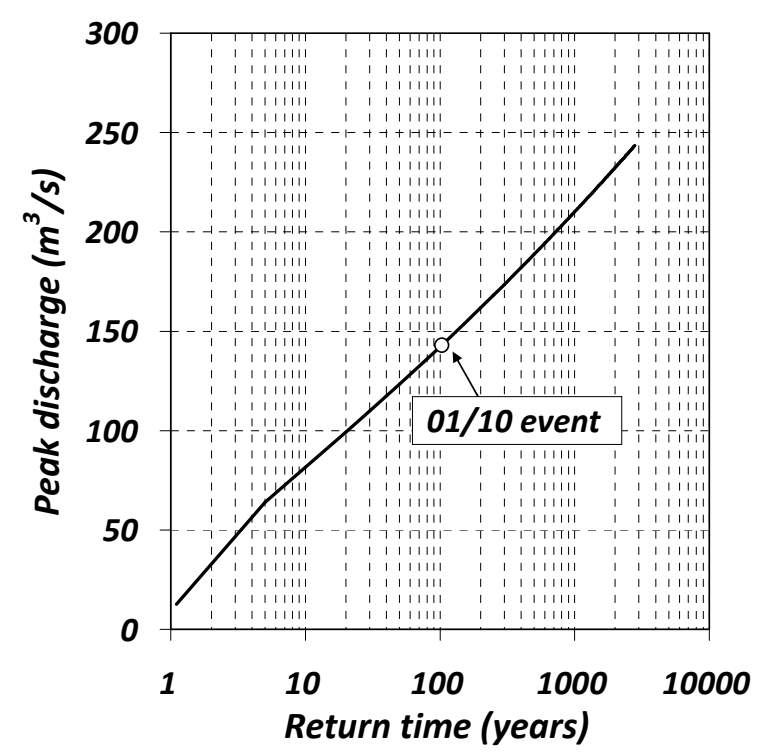

Fig. 12. Flood frequency curve.

2001; Gaume et al., 2004; Borga et al., 2008) showed considerable impact of initial soil moisture conditions on runoff from extreme flash floods. In particular, for a given storm event, different values of initial soil moisture conditions can discriminate between minor or catastrophic flooding effects (Brocca et al., 2010; Brocca et al., 2008; Berthet et al., 2009). The assessment of the susceptibility to flash flood, by taking initial soil moisture status into account, is a critical step to anticipate the locations of the river system which may be hit by the flood (Norbiato et al., 2008).

Dealing with ungauged catchment, usually the data available do not allow to correctly define the soil moisture conditions of the catchment; therefore, surrogate indexes which can take implicitly into account the antecedent soil moisture conditions (AMC) are in those cases extremely useful.

In hydrologic literature, three indices are usually used to describe AMC: the antecedent precipitation index (API), the antecedent baseflow index (ABFI) and the soil moisture index (SMI). In particular, API is based on the amount of antecedent rainfall, where the term "antecedent" varies from the previous 5 to 30 days. However, there are no explicit guidelines available to specify the variation of soil moisture with antecedent rainfall of a certain duration. The National Engineering Handbook (USDA-SCS, 1986) uses the antecedent 5-day rainfall as API for AMC. According to this procedure, three classes of soil moisture conditions are considered: dry soil $\left(\mathrm{AMC}_{\mathrm{I}}\right)$, moderately wet soil $\left(\mathrm{AMC}_{\mathrm{II}}\right)$ and wet soil $\left(\mathrm{AMC}_{\mathrm{III}}\right)$. Particularly, condition $\mathrm{AMC}_{\mathrm{I}}$ is characterised by a total 5 days antecedent rainfall less than $13 \mathrm{~mm}$ in the dormant season and less than $36 \mathrm{~mm}$ in the growing season. Condition $\mathrm{AMC}_{\mathrm{II}}$ is characterised by a total 5 days antecedent rainfall ranging from 13 to $28 \mathrm{~mm}$ in the dormant season and from 36 to $53 \mathrm{~mm}$ in the growing season. Condition $\mathrm{AMC}_{\mathrm{III}}$ involves a saturated soil with a total 5 days antecedent rainfall greater than $28 \mathrm{~mm}$ in the dormant season and greater than $53 \mathrm{~mm}$ in the growing season (USDA-SCS, 1986).

However, many authors (Sahu et al., 2007; Mishra et al., 2006; Michel et al., 2005) pointed out how this soil moisture accounting procedure shows major inconsistencies mainly due to a non-continues structure of the procedure itself.

Here, in order to characterise daily soil moisture conditions, instead of $\mathrm{API}_{5}$, an API calculated on a daily basis that assumes that soil moisture declines exponentially when there is no rainfall (Shaw, 1994) was used. This approach, developed and proposed by Brigandí (2009) and Brigandí and Aronica (2008), has the great advantage to return a parsimonious and easy-to-use procedure.

If there is rainfall, the API at the $n$ day can be derived as follow:

$\mathrm{API}_{n}=k \times \mathrm{API}_{n-1}+P_{n-1}$

with $k$ defined as follow: 


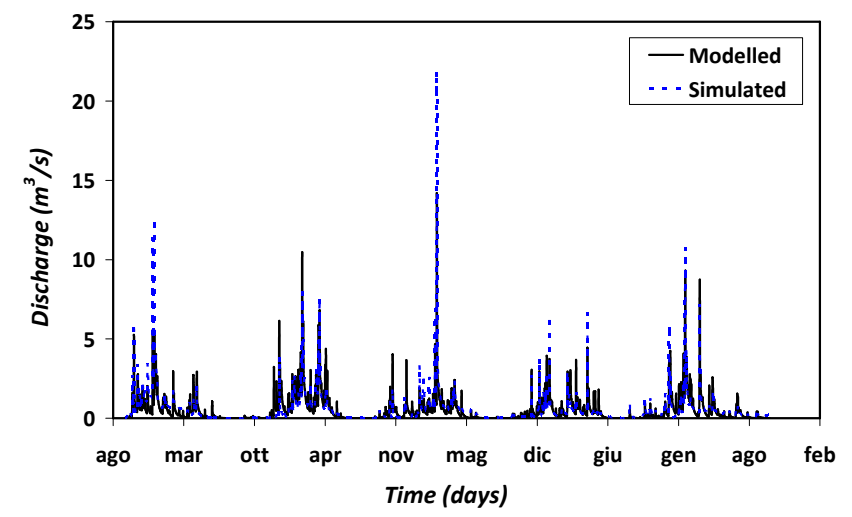

Fig. 13. Modelled and observed average daily discharge for the calibration period.

$k=e^{-\alpha \times \Delta t}$

where $\Delta T$ is assumed equal to 1 day, and the parameter $\alpha$ $\left(\right.$ day $\left.^{-1}\right)$ is the inverse of the characteristic time of the soil moisture depletion usually derived by calibration.

The API definition given by Eq. (9) implies, therefore, the need to derive a new classification to recognise the AMC classes as a function of the measured API in a single day. In order to derive this relationship, a series of soil moisture values calculated by applying the IHACRES model (Jakeman et al., 1990), already applied in Sicily for water resources management (Aronica, 2007), are analysed. Soil moisture values are expressed through the use of an index $s$, defined as follow:

$s_{t}=c \times r_{t}+\left(1-\frac{1}{\tau_{\mathrm{W}}\left(T_{k}\right)}\right) \times s_{t-1} ;$

where $s_{t}$ represents the catchment storage index, or catchment wetness/soil moisture index at time $t$, generally varying from 0 to $1, \tau_{\mathrm{w}}\left[T_{t}\right]$ is a time constant which is inversely related to the temperature declining rate, $c(\mathrm{~mm})$ is conceptual total storage volume chosen to constrain the volume of effective rainfall to equal runoff, and $r_{t}$ is the total rainfall at time $t$.

The AMC classes were constructed in order to incorporate approximately the same number of soil moisture observations. Then, the soil moisture contents corresponding to the 33rd and 66th percentiles were used to discriminate among the three classes as proposed in the NEH4- procedure (Mishra and Singh, 2003; Martina et al., 2006).

Because we are dealing with an ungauged catchment, for the purpose of this study, calibration was carried out using the data from another gauged Sicilian catchment (Elicona catchment, in the north east part of Messina), hydrologically similar to the Giampilieri river, and the $\alpha$ coefficient and the relationship between API and AMC were derived.

For the calculation of the daily API and the calibration of the $\alpha$ parameter, it is necessary to know the initial API value for the condition $t=0\left(\mathrm{API}_{0}\right)$. For this calculation, which concerns this value, taking into account the pluviometric regime of the area, characterised by high rainfall value during the winter season and low value during the summer season close to zero especially during July and August months, it was assumed that for the beginning of the hydrological year of the first year of calibration, $\mathrm{API}_{0}$ was equal to 0 . However, in order to reduce the influence of this initial hypothesis, the first period of calibration has to be ignored. After this period, in fact, it was verified that this initial assumption does not influence the daily API value. Finally, the parameter $\alpha$ was calibrated in order to have the best correlation between API and wetness index $s$. In order to take account of the non stationarity of the climate process because of the seasonal effects between wet and dry season, it is necessary to define the $\alpha$ parameter for each one of the two analysed seasons. Finally, the linear regression between the API and wetness index is performed to derive API values corresponding to 33rd and 66 th percentiles. Major details on the calibration procedure can be found in Brigandí (2009).

IHACRES model was calibrated against 5 yr (1976-1980) of daily rainfall series available from four raingauge stations (Falcone, Patti, Montalbano and Tripi) and average daily discharge from the flow gauging station Elicona at Falcone located at catchment outlet. The calibrated model had a NashSutcliffe efficiency of 0.696; Fig. 13 shows how the modelled discharge is in reasonable agreement with the observed discharge at Falcone. The AMC limits, according to percentiles of soil moisture contents, both for the wet and for the dry season, were fixed. The wetness index frequency analysis provided the soil moisture limits correspondent to the 33rd and 66th percentiles and provided $s$ values equal respectively to 0.127 and 0.384 . Calibration of the $\alpha$ parameter was carried out and resulted in a value of 0.025 (days $^{-1}$ ) for the wet season and a 0.042 (days $^{-1}$ ) for the dry season (Fig. 14). This process was given a correlation coefficient provided by the R-square parameter $R^{2}$ that confirms the goodness of the fit. The linear regression between the API and wetness index $s$ was calculated to derive the API values corresponding to 33rd and 66th percentiles for both the seasons and the obtained values are shown in Table 3 .

With these values the AMC classes for each day of September were derived and the obtained results are plotted in Fig. 15; the analysis of the graph confirms how the catchment was totally wet already some days before of the event. The three events that took place on September were the cause of the soil moisture saturation at the end of the month. Consequently, almost the totally rainfall of 1 October 2009 was transformed in runoff producing devastating effect at the soil. 

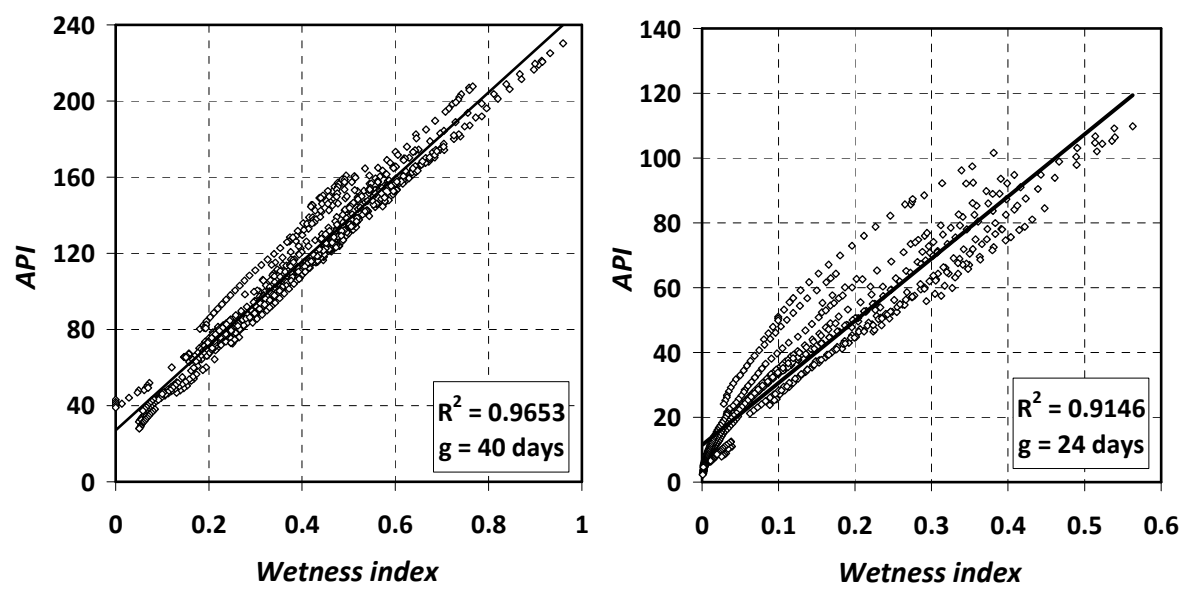

Fig. 14. Linear regression: API - $s$ : Wet season (left) and dry season (right).

Table 3. AMC-API limits.

\begin{tabular}{lcc}
\hline \multirow{2}{*}{ Antecedent Moisture Condition } & \multicolumn{2}{c}{ Antecedent Precipitation Index $(\mathrm{mm})$} \\
\cline { 2 - 3 } & $\begin{array}{l}\text { Wet season } \\
\text { (Sep-Mar) }\end{array}$ & $\begin{array}{c}\text { Dry season } \\
\text { (Apr-Aug) }\end{array}$ \\
\hline dry soil $\left(\mathrm{AMC}_{\mathrm{I}}\right)$, & $<55$ & $<35$ \\
moderately wet soil $\left(\mathrm{AMC}_{\mathrm{II}}\right)$ & $55 / 112$ & $35 / 78$ \\
wet soil $\left(\mathrm{AMC}_{\mathrm{III}}\right)$ & $>112$ & $>78$ \\
\hline
\end{tabular}

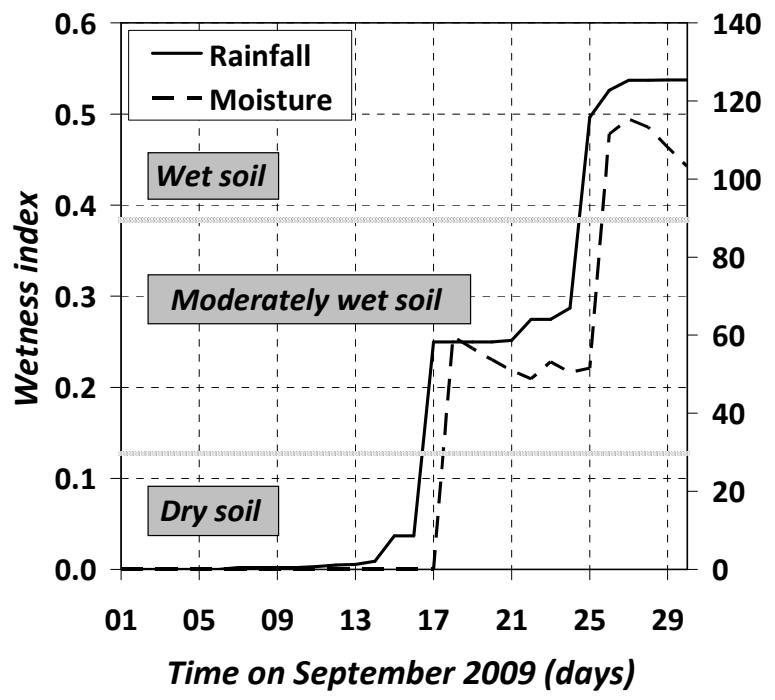

Fig. 15. Temporal distribution of the soil moisture condition for the Giampilieri catchment.

\section{Debris flow volume}

\subsection{Calculation process}

A series of open-source GIS-based algorithms using spatial analysis were used in order to perform the calculation of debris flows volume moved during the rainstorm (Rickenmann, 1999). Knowledge of the volume of debris flow events is a fundamental step to estimate the intensity (energy) of these phenomena and to assess risk for planning future defence systems and civil protection activities.

The volume of debris material was estimated by comparing data collected before and after the event (Fig. 16) as proposed in other studies (Barbarella et al., 2000; Fiani and Troisi, 1999).

Pre-event data was provided by existing contour maps issued of an aero-photogrammetric flight produced in 2002 with a resolution of $2 \mathrm{~m}$ in urban areas and $5 \mathrm{~m}$ in other areas. The post-event data was generated by a Laser flight performed a few days after the rainstorm event. The LiDAR technology used produced a $1 \mathrm{~m}$ resolution digital elevation model and ortophotos with a $15 \mathrm{~cm}$ pixel. In total, the LiDAR data on Giampilieri catchment covered eleven sheets. 


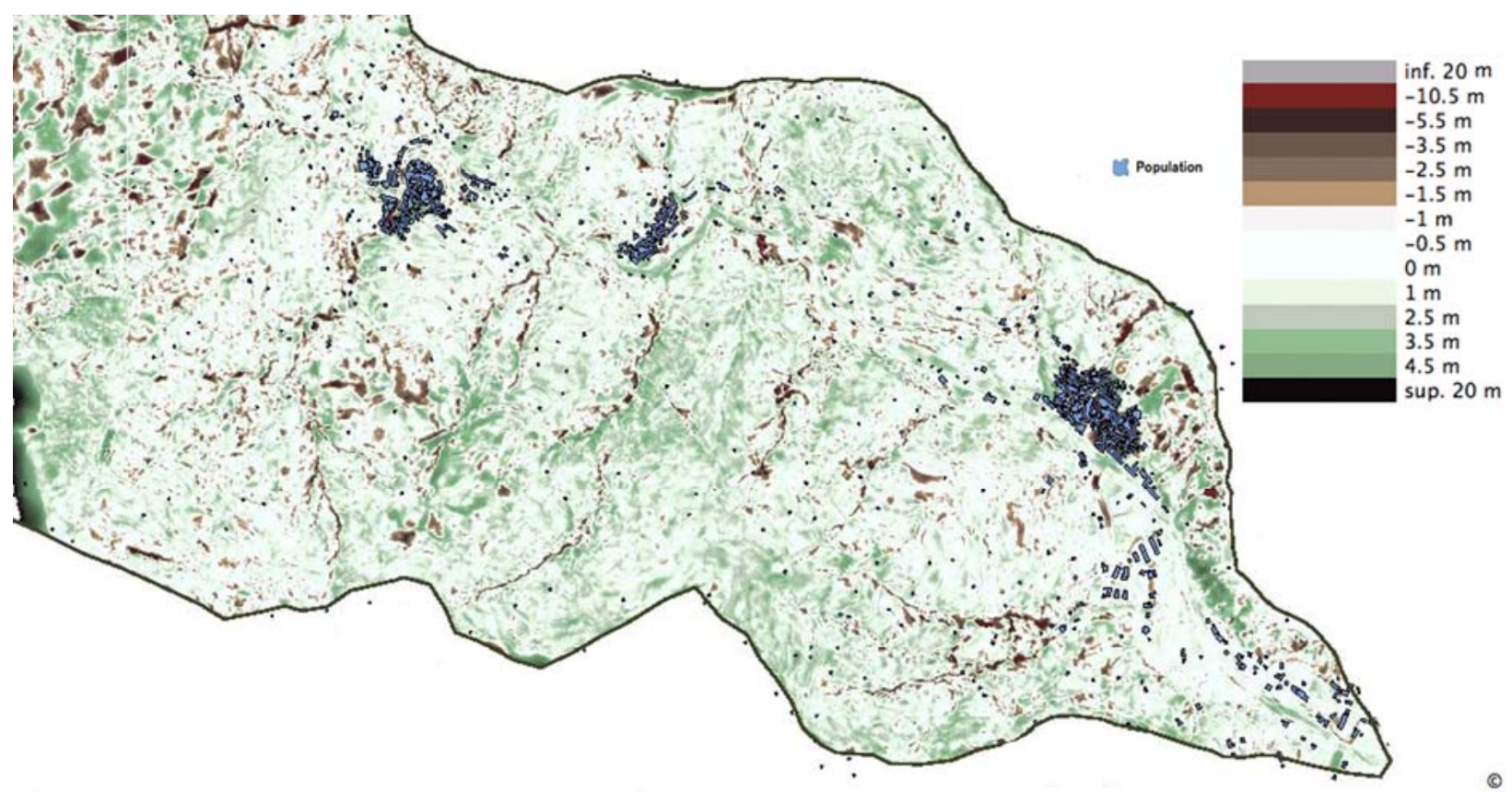

Fig. 16. Resulting volume.

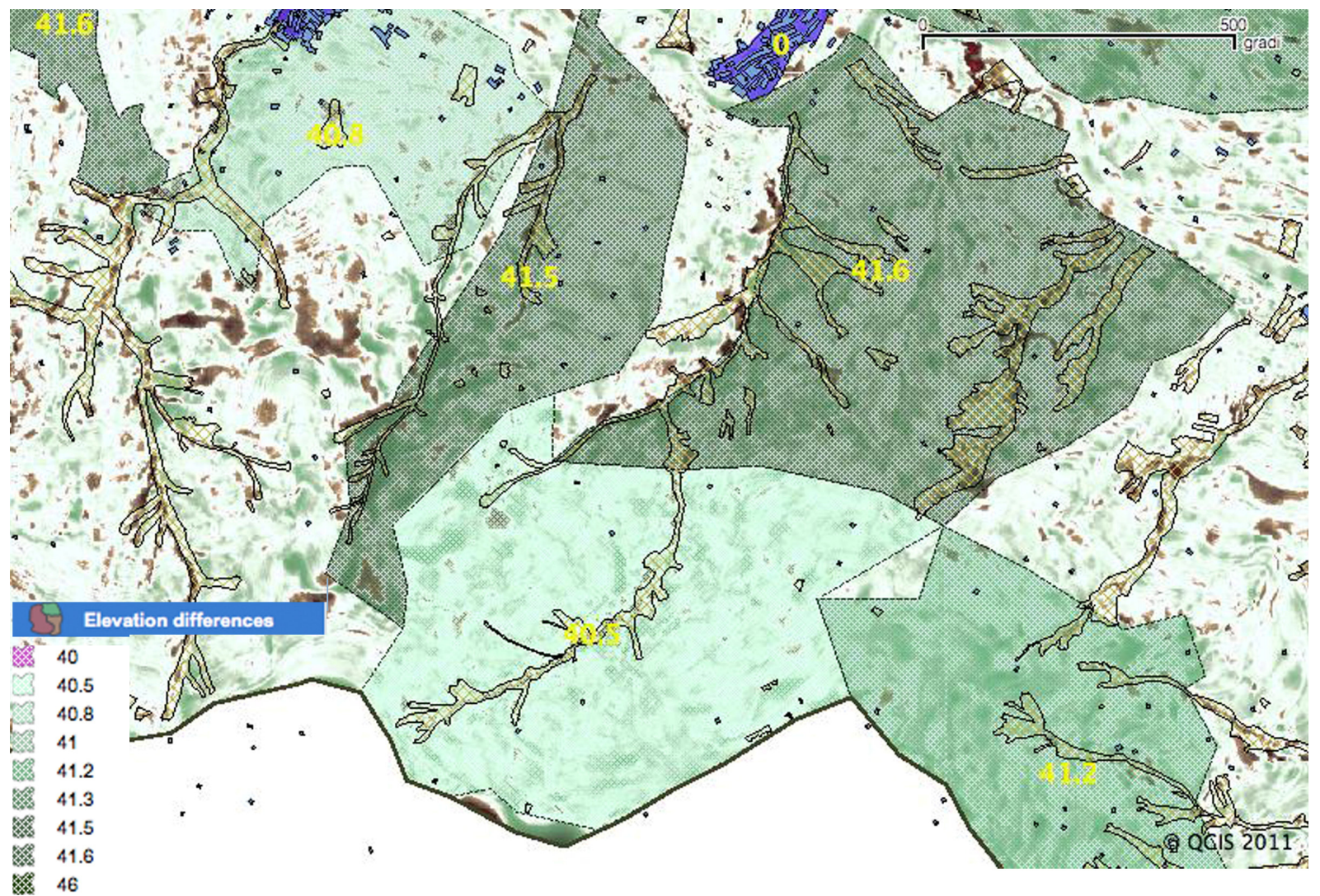

Fig. 17. Areas of minor/major elevation. 


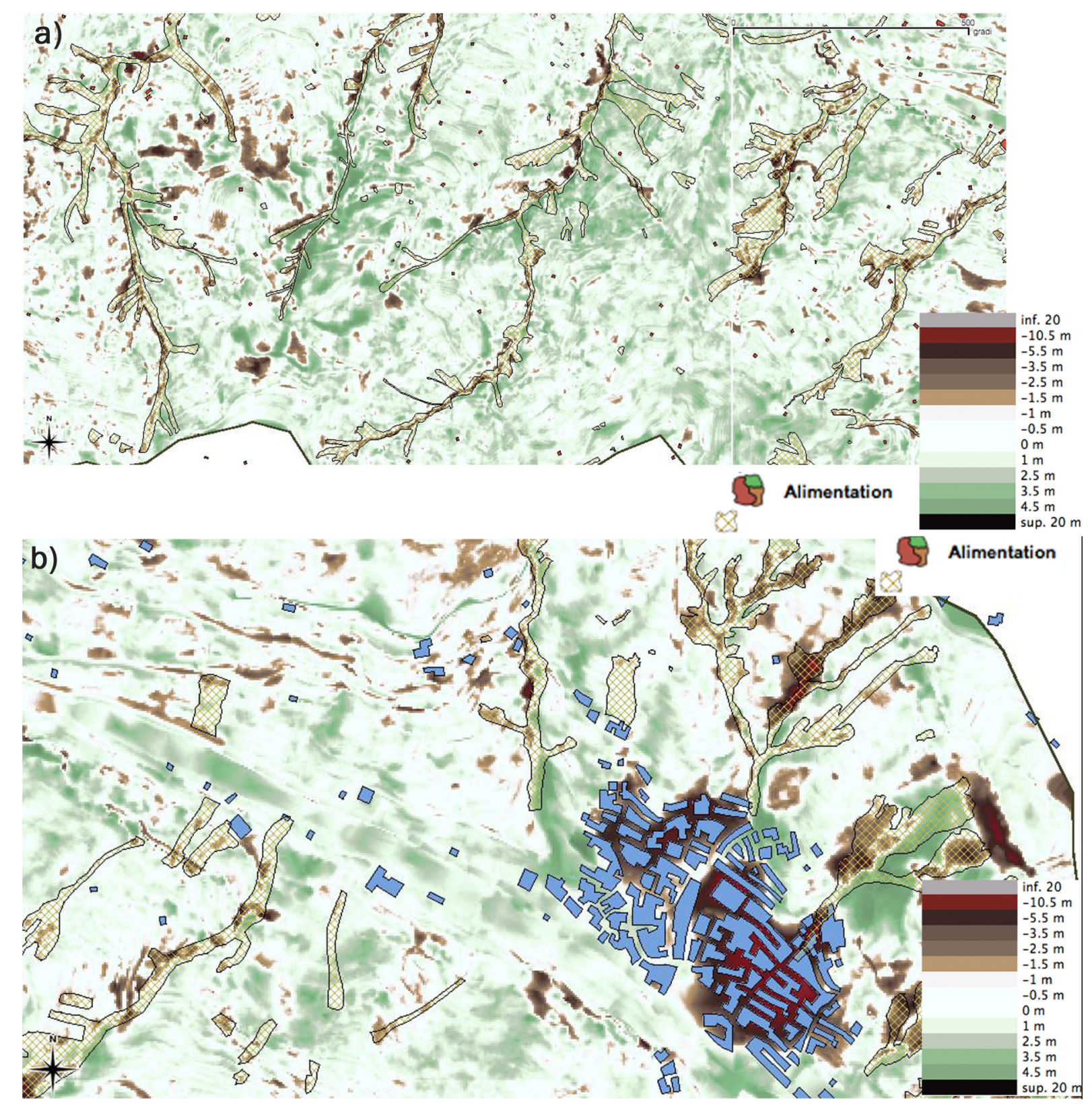

Fig. 18. (a) Comparison between resulting volume and slide areas observed on terrain. (b) Details on Giampilieri village.

The calculation process faced coordinate transformation and elevation problems between data using different projection systems and, moreover, datum types. In this specific study, the LiDAR data used global datum WGS84 while the existing geo-data information, which is the case of most national geo-information, used a local one. Most of the data in Italy, and especially in Sicily, are expressed in the GaussBoaga system reference, as the existing contour lines available for comparison. The main troubles concerned the land elevation comparison before and after the event with an elevation referred to as ellipsoid in the global datum system while as geoid for local one (Baiocchi et al., 2004). In main cases, the elevation difference was estimated around $40.3 \mathrm{~m}$ higher in WGS84. In the area of Giampilieri, no data reference was available for the altitude conversion. Some elevation difference grids were performed in order to establish some mathematical functions related to any possible relationships between coordinate ranges and geoid-ellipsoid elevation differences but no formula were found. However, the resulting map evidenced differences in zones of major/minor elevation. These zones were digitalised (Fig. 17). Calculation was successively readjusted with respect to the elevation difference reported in the digitalised zones, $40.3 \mathrm{~m}$ elsewhere. 


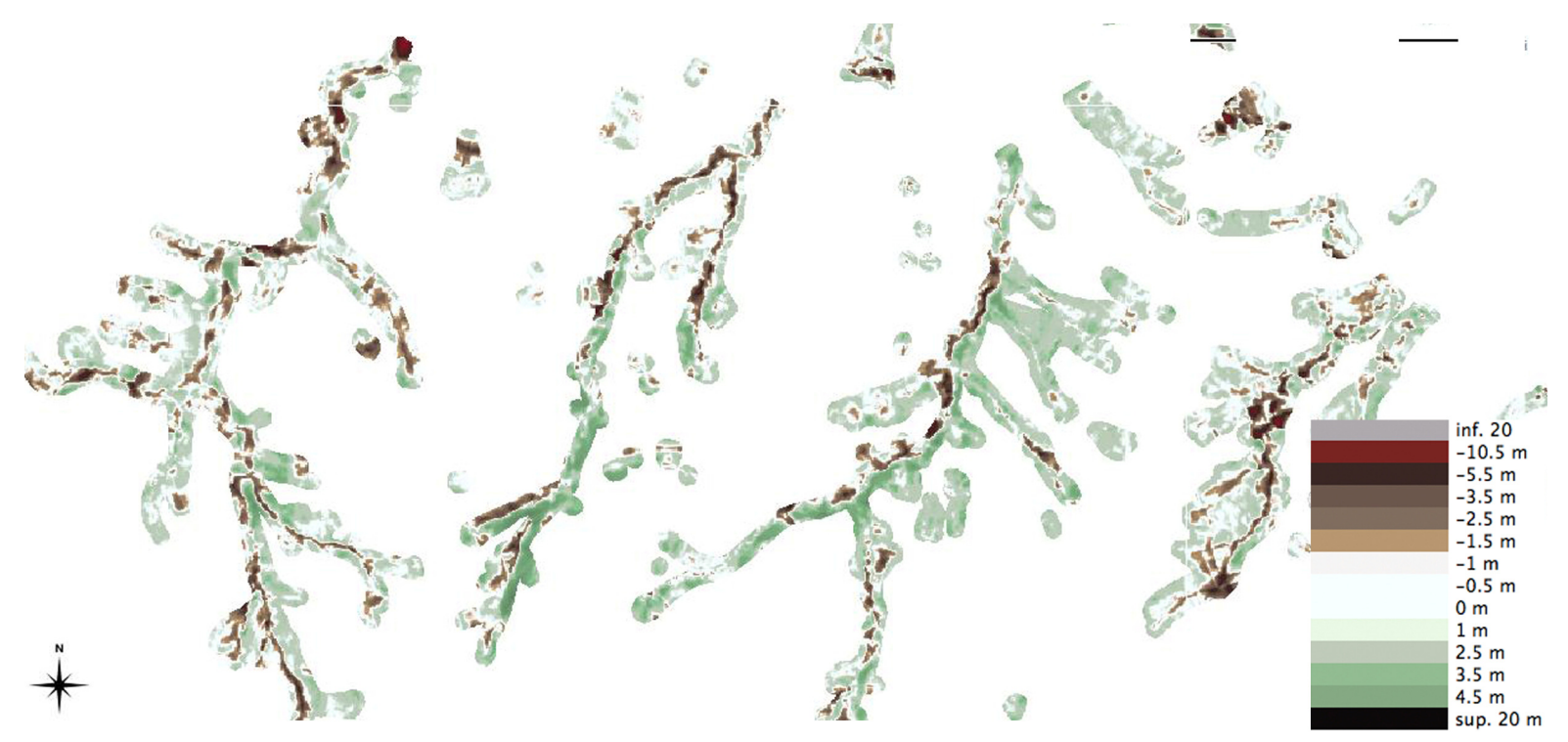

Fig. 19. Details of clipped volume.

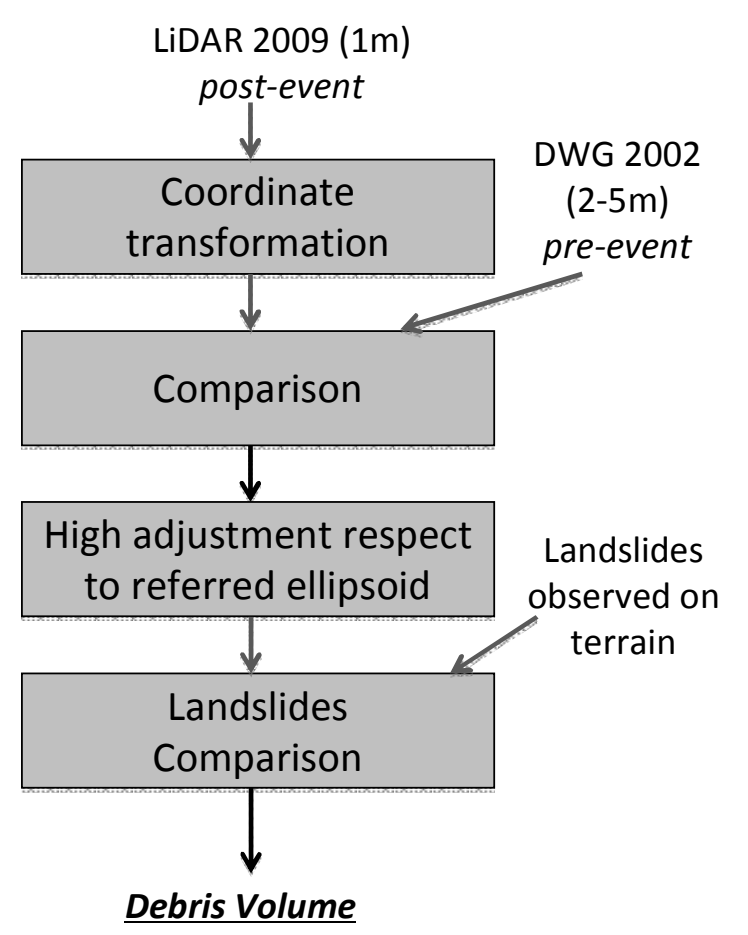

Fig. 20. Flow chart of debris volume calculation procedure.

At the same time of the volume computation, the National Agency for New Technologies, Energy and Development in Italy (ENEA) produced the maps of alimentation areas indicating zones of debris flows inside the catchment. Data were produced from a terrain analysis survey performed a few days after the disaster and, in situation of inaccessible places, through the analysis of the orthophotos that were generated by the LiDAR flight. Our calculated volume map matched this landslide area in a satisfactory way (Fig. 18a and b). Furthermore, in a few cases the volume map evidenced areas not identified by ENEA work.

Because of the elevation sensitivity due to coordinate system references, it was decided to delimitate a buffer of $10 \mathrm{~m}$ around these observed landslide zones. Only the areas inside the defined buffers were considered in the calculation (Fig. 19).

In a few cases, some contour lines were missing in populated places like the center of Giampilieri Superiore. However, this lack of information was not concerned by the buffer taken into account since the referred locations were not involved by the material mobilised.

For volume calculation, open-source GIS solutions were chosen like QGIS for map representation, GRASS for operations on raster and vectors, free cartographic libraries, as Gdal helped in raster data transformation and merging. Traspunto was successfully used for vector coordinate transformation. The block diagram of the implemented procedure is shown in Fig. 20, and the volume of debris calculated was estimated equal to $780000 \mathrm{~m}^{3}$ for an area of $600000 \mathrm{~m}^{2}$.

\subsection{Accuracy and standard of data}

The computation process points out the importance of working with validated and accurate data. For the case in study, the LiDAR techniques generated a high resolution DEM with an elevated reliability and accuracy of data as required in hydrological analysis problems. Previously, for the DEM comparison, a $2 \mathrm{~m}$ resolution DEM generated in 2007 after an areo-photogrammetric flight were used as the pre-event elevation map instead of the contour maps. The resulting 
volume did not match the ENEA landslides observed on terrain. After an accurate analysis, it was observed that the DEM from 2007 furnished by the regional administration contained numerous bad elevation data. The DWG data from 2002 , although dated and with a low resolution, fit better to reality.

Also, use of a common reference system is necessary for data integrity. That is the case of the elevation considered in different system of datum as illustrated in our application. The problem is resolved in GPS applications where WGS84 has become the standard coordinate system reference. Moreover, system reference standards avoid loss of time and error generation in raster map coordinate transformations. In Europe, the INSPIRE directive (INSPIRE directive 2007/2/EC) is defining standard specifications for geoinformation exchange. The elevation is one of themes the organisation is working on. Homogenous data and coordinate references should help Public Administrations in saving money and time in geo-data reuse. However, in hydrological risk, height problem resolution is remaining as for our application where the elevation grid provided by the European Vertical Reference System (EVRS, 2007) as well as the Italian one, cannot be used since the resolution supplied is over the $1-2 \mathrm{~m}$ required.

\section{Conclusions}

The aim of the present paper was to analyse the 1 October 2009 flash flood and debris flow event that occurred in the area of Messina, Sicily, and highlight the destructive potential of this kind of natural hazard. The study confirmed that post-flood investigation should focus on discharges and hydrological response of the catchment rather than simply analysing statistical characteristics of rainfall.

Rain gauge observations allowed, in fact, an assessment of the magnitude of the rain event, which is particularly remarkable by its spatial concentration in the area around Giampilieri with rain amounts greater than $200 \mathrm{~mm}$ in less than $4 \mathrm{~h}$ with a peak of about $120 \mathrm{~mm} \mathrm{~h}^{-1}$ in $10-\mathrm{min}$. However, the hydrological analysis performed suggested that the event was not significant for storm severity that was estimated equivalent of a 1 in about $30 \mathrm{yr}$ return time. Therefore, postevent investigation outlined the importance of hydrologicalhydraulic response of the catchment rather than the rainfall characteristics not only for a more accurate even portrayal, but also because catchment wetness conditions played a decisive role in the final consequences of the event.

The influence of antecedent saturation conditions on runoff formation was analysed by considering an antecedent precipitation index derived on a daily basis. Analysis of the results show a significant impact of the antecedent conditions on flood formation, challenging the common wisdom that antecedent soil moisture is of little importance in determining of the extreme flash floods.
For the debris volume computation, because of nonhomogeneous coordinate references used by the available DEMs, a simple comparison between elevation maps of different periods as proposed in other studies was not sufficient to estimate the real volume of debris moved. The analysis method adopted for the debris volume evaluation gave satisfied results. Initiatives should be taken into account, such as for GPS applications, to define common model and system references for geo-data exchange, which will help administration organisations to gain time and money in geo-data reuse and comparison.

Edited by: K. Lagouvardos

Reviewed by: T. Rigo and another anonymous referee

\section{References}

Alcoverro, J., Corominas, J., and Gómez, M.: The Barranco de Arás flood of 7 August 1996 (Biescas, Central Pyrenees, Spain), Eng. Geol., 51, 237-255, 1999.

Aronica, G. T.: Continuous-time modelling of hydrologic time series hydrological conceptual models, Water Resources Assessment under Water Scarcity Scenarios, edited by: La Loggia, G., Aronica, G. T., and Ciraolo, G., CSDU, Milano, 205-225,2007.

Aronica, G. T. and Candela, A.: Derivation of flood frequency curves in poorly gauged Mediterranean catchments using a simple stochastic hydrological rainfall-runoff model, J. Hydrol., 347, 132-142, 2007.

Aronica, G. T., Brigandí, G., Marletta, C., and Manfrè, B.: Hydrological and hydraulic analysis of the flash flood event on 25 October 2007 in North-Eastern part of Sicily, Italy, Proceedings of Floodrisk 2008, Oxford (UK), 2008.

Baiocchi, V., Bortolotti, C., Crespi, M., and Del Moro, M. A.: Accuratezza delle trasformazioni tra Datum e Sistemi Cartografici Nazionali implementate nei software di maggiore utilizzo nelle applicazioni GIS, Proceedings of the 8th National Conference ASITA, I, 195-200, Roma, 2004.

Barbarella, M., Fazio, C. and Fiani, M.: Evaluation of landslide volume using photogrammetric techniques, IAPRS, vol. XXXIII, 2000.

Berthet, L., Andréassian, V., Perrin, C., and Javelle, P.: How crucial is it to account for the antecedent moisture conditions in flood forecasting? Comparison of event-based and continuous approaches on 178 catchments, Hydrol. Earth Syst. Sci., 13, 819831, doi:10.5194/hess-13-819-2009, 2009.

Borga, M., Boscolo, P., Zanon, F., and Sangati, M.: Hydrometeorological analysis of the August 29, 2003 flash flood in the eastern Italian Alps, J. Hydrometeorol., 8, 1049-1067, 2007.

Borga, M., Gaume, E., Creutin, J. D., and Marchi, L.: Surveying flash floods: gauging the ungauged extremes, Hydrol. Process., 22, 3883-3885, 2008.

Brigandí, G.: Il preavviso delle piene in bacini non strumentati attraverso l'uso di precursori idro-pluviometrici, $\mathrm{PhD}$ thesys dissertation, Università di Palermo, Italy, 2009.

Brigandí, G. and Aronica, G. T.: Operational flash flood forecasting chain using hydrological and pluviometric precursors, Proceedings of Floodrisk 2008, Oxford (UK), 2008. 
Brocca, L., Melone, F., Moramarco, T., Wagner, W., Naeimi, V., Bartalis, Z., and Hasenauer, S.: Improving runoff prediction through the assimilation of the ASCAT soil moisture product, Hydrol. Earth Syst. Sci., 14, 1881-1893, doi:10.5194/hess-141881-2010, 2010.

Brocca, L., Melone, F., and Moramarco, T.: On the estimation of antecedent wetness condition in rainfall-runoff modelling, Hydrol. Process., 22, 629-642, 2008.

Burlando, P. and Rosso, R.: Le precipitazioni intense, La sistemazione dei corsi d'acqua naturali, edited by: Maione, U. and Brath, A., Editoriale Bios, 1995.

Cannarozzo, M., D’Asaro, F., and Ferro, V.: Regional rainfall and flood frequency analysis for Sicily using the two component extreme value distribution, J. Hydrol. Sci., 40, 23-34, 1995.

Chow, V. T., Maidment, D. R., and Mays, L. W.: Applied Hydrology, McGraw-Hill International Editions, 1988.

Doswell III, Ch. A., Brooks, H. E., and Maddox, R. A.: Flash Flood Forecasting: An Ingredients-Based Methodology, Weather Forecast., 11, 560-581, 1996.

Fiani, M. and Troisi, S.: DEM's comparison for the evaluation of landslide volume, Proceedings of ISPRS WG VI/3 Meeting International Cooperation and Technology Transfer, Parma, 1999.

Gaume, E., Bain, V., and Bernardara, P.: Primary Flash flood Data, Work Package 1 Report for HYDRATE, EC Project No. GOCECT-2004-505420, 2008.

Gaume, E., Livet, M., Desbordes, M., and Villeneuve, J-P.: Hydrologic analysis of the Aude, France, flash-flood 12 and 13 November 1999, J. Hydrol., 286, 135-154, 2004.

Georgakakos, K. P.: On the design of national, real-time warning systems with capability for site-specific, flash-flood forecasts, Bull. Am. Meteorol. Soc., 67, 1233-1239, 1986.

Hosking, J. R. M. and Wallis, J. R.: The Effect of Intersite Dependence on Regional Flood Frequency Analysis, Water Resour. Res., 24, 588-600, 1988.

Hosking, J. R. M. and Wallis, J. R.: Some statistics useful in regional frequency analysis, Water Resour. Res., 29, 271-281, 1993.

Hosking, J. R. M. and Wallis, J. R.: Regional frequency analysis: an approach based on L-moments, Cambridge University Press, Cambridge, UK, 1997.

Huet, Ph., Martin, X., Prime, J-L., Foin, P., Laurain, Cl., and Cannard, Ph.: Retour d'expériences des crues de septembre 2002 dans les départements du Gard, de l'Hérault, du Vaucluse, des bouches du Rhône, de l'Ardèche et de la Drôme, Inspection générale de l'Environnement, Paris, France, 124 pp., 2003.

INSPIRE: Directive 2007/2/EC of the European Parliament and of the Council of 14 March 2007 establishing an Infrastructure for Spatial Information in the European Community, 2007.

Jakeman, A. J., Littlewood, I. G., and Whitehead, P. G.: Computation of the instantaneous unit hydrograph and identifiable component flows with application to two small upland catchments, J. Hydrol., 117, 275-300, 1990.

Jenkinson, A. F.: The frequency distribution of the annual maximum (or minimum) values of meteorological events, Q. J. R. Meteorol. Soc., 81, 158-171, 1955.

Kirpich, Z. P.: Time of concentration of small agricultural watersheds, Civil Eng., 10, 362 pp., 1940.

Kottegoda, N. T. and Rosso, R.: Statistics, Probability and Reliability for Civil and Environmental Engineers, McGraw-Hill Inter- national, 1998.

Llasat, M. C., De Batlle, J., Rigo, T., and Barriendos, M.: Las Inundaciones del 10 de Junio del 2000 en Catalana, Revista Ingenieria del Agua, 8, 53-66, 2001.

Maidment, D. R.: Handbook of hydrology, McGraw-Hill, New York, 1992.

Martina, M. L. V., Todini, E., and Libralon, A.: A Bayesian decision approach to rainfall thresholds based flood warning, Hydrol. Earth Syst. Sci., 10, 413-426, doi:10.5194/hess-10-413-2006, 2006.

Messina, A., Russo, S. and Stagno, F.: The crystalline basements of the Calabrian-Peloritani Arc, 6th field Meeting IGCP Project no 276, "The Calabrian-Peloritani Arc and its correlation with Northern Africa and Southern Europe, Messina, 27 Settembre-2 Ottobre 1993, Newsletter 6, 94 pp., 1996.

Michel, C., Andreassian, V., and Perrin, C.: Soil Conservation Service Curve Number method: How to mend a wrong soil moisture accounting procedure?, Water. Resour. Res., 41, W02011, doi:10.1029/2004WR003191, 2005.

Mishra, S. K., Sahu, R. K., Eldho, T. I., and Jain, M. K.: An Improved Ia-S Relation Incorporating Antecedent Moisture in SCSCN Methodology, Water. Resour. Manag., 20, 643-660, 2006.

Mishra, S. K. and Singh, D. P.: Soil Conservation Service Curve Number (SCS-CN) Methodology, Water Sciences and Technology Library, 2003.

Norbiato, D., Borga, M., Degli Esposti, S., Gaume, E., and Anquetin, S.: Flash flood warning based on rainfall threshold and soil moisture conditions. An assessment for gauged and ungauged basins, J. Hydrol., 362, 274-290, 2008.

Noto, L. V. and La Loggia, G.: Use of L-moments approach for regional flood frequency analysis in Sicily, Italy, Water Resour. Manag., 23, 2207-2229, 2009.

Regional Department of Civil Protection for Sicily: Relazione descrittiva sull'emergenza colate di fango nel territorio della provincia di Messina, Italia, 1 ottobre 2009, Internal Report, 2009 (in Italian).

Rickenmann, D.: Empirical relationships for debris flows, Nat. Hazards, 19, 47-77, 1999.

Rossi, F., Fiorentino, M., and Versace, P.: Two components extreme value distribution for flood frequency analysis, Water Resour. Res., 20, 847-856, 1984.

Sahu, R. K., Mishra, S. K., Eldho, T. I., and Jain, M. K.: An advanced soil moisture accounting procedure for SCS curve number method, Hydrol. Process., 21, 2872-2881, 2007.

Shaw, E. M.: Hydrology in practice, Routledge Edn., 1994.

Sturdevant-Rees, P., Smith, J. A., Morrison, J., and Baeck, M.L.: Tropical storms and the flood hydrology of the central Appalachians, Water Resour. Res., 37, 2143-2168, 2001.

Sweeney, T. L.: Modernized areal flash flood guidance, NOAA Technical Report NWS HYDRO 44, Hydrologic Research Laboratory, National Weather Service, NOAA, Silver Spring, MD, October, 21 pp. and an appendix, 1992.

US Department of Agriculture: Soil Conservation Service, National Engineering Handbook, Hydrology, Sec.4, Washington DC, 1986.

USGS: Natural hazards on alluvial fans: The Venezuela debris flow and flash flood disaster, fact Sheet 2001-0103, 2001.

USGS: A NOAA-USGS Demonstration Flash flood and DebrisFlow Early-Warning System, fact Sheet 2005-3104, 2005. 